\title{
Study on the promotion effects of stock market on Guizhou economy development
}

\author{
Chenggang $\mathrm{Li}^{1,}$, , Yandan Xue $\mathrm{X}^{1, \mathrm{~b}}$ \\ ${ }^{1}$ Faculty of Finance, Guizhou University of Finance and Economics, Guiyang, 550025 \\ a895977948@qq.com,b1532895790@qq.com
}

Keywords: stock market; economic growth; functional mechanisms

\begin{abstract}
Studying on the relationship between the stock market and economic development in Guizhou Province can help to promote the development of the stock market and economic development in Guizhou Province. Selecting the data from 2000 to 2013 of Guizhou Province, this paper uses multivariate regression model to empirically analyze the promotion effects of the stock market on the economic development in Guizhou Province. The empirical results show that: Guizhou stock market capitalization rate, transaction value and turnover have a significant positive impact on economic development. Equity division reform affecting economic development in Guizhou Province is not significant.
\end{abstract}

\section{Introduction}

Guizhou Province is located in the southwest of China, where the economy has been in the underdeveloped level. Its economic development was always on the focus of the government and academia. Since the establishment of China stock market, Guizhou Province has a total of more than 20 enterprises publicly traded stocks. The total fund-raising is more than 21.5 billion yuan. There output value accounts for $15 \%$ of the provincial GDP on average per year.The annual added value of the national economy in Guizhou Province was 7.5 per cent of GDP. Moreover, many of the listed companies in Guizhou Province laid the status of industry leader.Some listed companies determine the basis of the status of the industry in China. Research scholars have begun to pay attention to stock market development in Guizhou Province. What kind of role does the stock market play in the economic growth in Guizhou Province? How to define the role of the stock market in economic growth in Guizhou Province? Researching on these issues is conducive to economic development and stock market development in Guizhou Province, which has important practical significance.

\section{Literature Review}

In academia, there are a lot of theoretical and empirical researches on the interaction of the stock market and economic development. Raymond and Jovanovic's (1993) study shows that the stock market can adjust economic structure and promote economic growth. Under the framework of a simple Keynesian national economic identity, Lu (2007) explores the interaction between Chinese stock market and economic development. The study shows that the relationship between the stock market and economic growth is not significant, and there is a certain negative correlation. Chen (2009) uses the Econometric analysis methods, such as co-integration analysis and Granger causality test, to study the role of the stock market in promoting China's economic development. The results show that, there is a weak correlation between the stock price and investment development. Economic development has an important influence and role on the stock market. But the role of the stock market on economic growth is not significant. Based on monthly data from 1980 to 2004, Gregoriou (2009) uses the ARCH model to empirically analyze the relationship between the return on the US stock market and the economy. He find that the fluctuations in the stock market reflect the real economic situation. They influence the consumption and money supply of entity economy through the decision-making of the financial sector, and further affects the overall level of economic output. Using the China's stock market data from 1993 to 2014, from theoretical and empirical viewpoint, Zhou(2015) investigates the relationship between significant changes in stock prices and the real 
economy. The results show that there isn't obvious correlation between China's stock price volatility and investment growth. There is less impact on investment growth, and the impact on consumption growth is not significant. Based on currency circulation model, Lu et al. (2015) analyze the promotion impact of fund getting into the stock market on the real economy from the equity financing, equity investments, securities, wealth effect, balance sheet analysis, and service outputs, respectively. The results show that money getting to the stock market can sustain the economic system monetary circulation balance, and promote economic entity development.

It is easy to see from the literature research above, economists have explored the interactive relationship between the stock market and economic development based on different theoretical and empirical researches. Because of different theories and analysis models, the research results have their own characteristics. The relationship between the stock market and economic development has not yet formed a conclusion. In this paper, according to the literature of stock market in Guizhou Province,we build a multiple regression model, and empirically research the promoting effect of the stock market on economic development in Guizhou Province.

\section{Empirical Analysis of the promotion effects of Stock Market on economic growth in Guizhou Province}

Although the development of stock market in Guizhou Province is rapid, there are some deficiencies and defects for the current stock market promoting economic development in Guizhou Province. Therefore, this paper selects the scale of Guizhou stock market (capitalization rate, CAP), capital liquidity (transaction value, VAL and turnover, TUR), system changes (Split Share Structure Reform, NTS), fixed assets investment rate (INV) and the household savings rate (SAV) to do regression analysis on the economic development of Guizhou. We aim to show whether the stock market significantly positively promote the economic growth in Guizhou Province.

\section{Regression Model and Estimation}

The paper constructs econometric analysis model to test the the role and effect of the stock market on the economic development. The model is shown as follows:

$$
R G D P=\beta_{0}+\beta_{1} \text { Stock }+\beta_{2} C_{t}+\varepsilon_{t}
$$

In the model (1), the growth rate of the gross production of the Guizhou economy is explanatory variable, and the growth rate is represented by logarithm. $\beta_{0}$ in the model is constant. Stock is the vector that represented stock market development in Guizhou Province[capitalization rate (CAP), the transaction value (VAL), turnover (TUR) and Split Share Structure Reform (NTS)]; C indicates the selected control variable vector [fixed assets investment rate (INV), total imports to GDP ratio (TRA), household savings rate (SAV), the balance of the loan with quarterly GDP ratio (DEP) and total government expenditure (EXP)]. $\beta_{1}$ indicates the stock market index weighting coefficients. It is worth our concern that, if the results of $\beta_{1}$ are positive, as well as significant, it proves that there is a significant positive correlation between the stock market and economic development of Guizhou. Conversely, it indicates a negative relationship.

In this paper, the data come from the "Guizhou Provincial Statistical Yearbook", which are from 2000 to 2013. In order to reduce heteroscedasticity,we take the logarithm of the above variables.

To estimate parameters of the model (1), we take the variables (LCAP, LVAL, LTUR and LNTS) under control, then do regression analysis on LRGDP respectively. The results shown in Table 1.

Table 1 Regression analysis

\begin{tabular}{|c|c|c|c|c|c|c|c|c|}
\hline Variables & Coef & $\begin{array}{c}\mathrm{t}- \\
\text { Statistic }\end{array}$ & Prob. & $\begin{array}{c}\text { Adjvsted } \\
\text { R-Square }\end{array}$ & AIC & D-W. & $\begin{array}{c}\text { F- } \\
\text { statistic }\end{array}$ & $\begin{array}{c}\text { Prob } \\
\text {-statistic }\end{array}$ \\
\hline LCAP & 0.1303 & 3.3870 & 0.0107 & 0.7016 & -1.801 & 2.1105 & 10.4761 & 0.0000 \\
\hline LVAL & 0.0174 & 3.0505 & 0.0210 & 0.6177 & -1.6445 & 1.9124 & 7.3034 & 0.0000 \\
\hline LTUR & 0.0401 & 4.5705 & 0.0070 & 0.6200 & -1.6745 & 1.9029 & 7.5519 & 0.0000 \\
\hline LNTS & 0.3240 & 0.0368 & 0.7055 & 0.6217 & -1.6817 & 2.0683 & 7.6275 & 0.0000 \\
\hline
\end{tabular}




\section{Regression Analysis}

Estimation results in Table 1 show that overall regression conclusion of the model (1) is basically reasonable. The every adjusted $\mathrm{R}^{2}$ of the model are all higher than 0.6 . The accompanied probability of $\mathrm{F}$ test is zero. This indicates that there is a strong linear relationship between the variables. D-W values are all about 2 , so there is no multicollinearity. These estimation results show that there is a significant correlation between the stock market and economic development in Guizhou Province.

Based on the regression analysis, the conclusions are as the follows:

First, the coefficient of the stock market capitalization rate of Guizhou Province 0.1303, and it is positive and significant. This shows that the stock market capitalization rate of Guizhou Province has a significant positive impact on economic development. Improving the stock market capitalization rate of Guizhou Province can significantly promote economic development in Guizhou Province.

Second, the coefficient of stock market transaction value in Guizhou Province is 0.0174. The coefficient of the turnover is 0.0401 . These two coefficients are also positive and significant. This shows that the stock market transaction value and turnover have a significant impact on economic development in Guizhou Province. The higher the stock market transaction value and turnover are, the better the stock market liquidity is, and a high stock market liquidity can promote economic development in Guizhou Province.

Third, the coefficient of Split Share Structure Reformis 0.3240, It is positive, but not significant. This shows that the Split Share Structure Reform has little effect on the stock market in Guizhou Province, and its effect on economic development is not significant.

\section{Conclusions and policy recommendations}

Selecting data from the year 2000 to 2013, this paper uses multivariate regression model to empirically analyze the promoting effects of the stock market on the economic development in Guizhou Province. The empirical results show that: stock market capitalization rate, transaction value and turnover have a significant positive impact on economic development in Guizhou Province. While the affect of Split Share Structure Reform on economic development in Guizhou province is not significant.

As to the promoting effect of the stock market on economic in Guizhou Province, the paper proposes the following policy recommendations:

Firstly, supporting the development of the stock market. Actively cultivate the preparing for listing companies, support and develop the high-tech industries with vast potential market,and actively promote the best companies in Guizhou Province to IPO.Build bridges between the stock market and economic development, and enhance the overall economic development and industrial structure in Guizhou Province.

Secondly, improve the operate environment of the stock market. Strengthen the support to the listed enterprise in GuiZhou Province. For the new enterprise that with large scale, well development prospects, good inner-control system, government should take unified plan, and strengthen supervision to lay a solid foundation for the rapid economic development in Guizhou Province.

Thirdly, Establish reasonable ownership structure, change the mainly state-controlled phenomenon. Reasonable ownership structure can encourage business managers. Therefore, the listed companies should enhance the internal management incentives to maximize the enthusiasm of corporate management personnel and initiative, and achieve their overall development and economic interests of shareholders.

\section{References}

[1] R. Atje, B. Jovanovic. Stoke Markets and Development [J]. European Economic Review, 1993, (2-3): 632-640.

[2] X. Lu. The effect of stock market development on economic growth in China [J]. World Economic Outlook, 2007, (3): 49-52. 
[3] Y. Chen. An Empirical Research on the Relationship between Stock Market and Economic Growth in China [J]. Economic Survey, 2009, (4):28-30.

[4] A. Gregoriou, J. Hunter, F. Wu. An Empirical Investigation of the Relationship between the Real Economy and Stock Returns for the United States [J]. Journal of Policy Modeling, 2009, 31(1): 133-143.

[5] X. Zhou. The transmission mechanism and Empirical Study on the impact of stock price volatility on Chinese real economy: Based on Chinese market data from 1993 to 2014 [J]. Financial Theory \& Practice, 2015, (8): 93-97.

[6] M. Lu, Z. Li, T. Wang. The relationship between stock market and real economy: a study based on the model of monetary circulation flow [J]. South China Finance, 2015, (7): 4-12. 